\title{
EKSTRAK KUERSETIN KULIT UMBI BAWANG MERAH (Allium cepa L.) KINTAMANI SEBAGAI KRIM ANTIINFLAMASI PADA MENCIT PUTIH JANTAN Mus Musculus DENGAN METODE HOT PLATE
}

\author{
(EXTRACT OF KINTAMANI RED ONIONSKIN (Allium cepa L.) AS ANTIINFLAMATION \\ CREAM ON Mus Musculus WHITE MICE WITH HOT PLATE METHOD)
}

\author{
DEBBY JULIADI*•, NI PUTU DEWI AGUSTINI* \\ *Fakultas Farmasi Universitas Mahasaraswati Denpasar, Jalan Kamboja No.11 A, Denpasar, Bali
}

\begin{abstract}
Abstrak: Inflamasi atau radang merupakan reaksi lokal jaringan terhadap infeksi atau cedera dan melibatkan lebih banyak mediator. Inflamasi memiliki angka kejadian yang cukup tinggi, dimana inflamasi dapat disebabkan oleh trauma fisik, infeksi maupun reaksi antigen dari suatu penyakit. Salah satu tanaman yang dapat digunakan sebagai antiinflamasi adalah bawang merah (Allium cepa L.). Bawang merah memiliki kandungan senyawa flavonoid yaitu kuarsetin yang diyakini dapat digunakan sebagai antiinflamasi. Ekstraksi dilakukan secara maserasi mengunakan pelarut etanol 96\%, lalu ekstrak diformulasikan menjadi krim M/A dan dievaluasi mutu fisik meliputi uji organoleptis, uji homogenitas, uji $\mathrm{pH}$, uji daya sebar, uji daya lekat dan uji stabilitas pada hari 1 sampai minggu ke 6. Hasil penelitian yang telah dilakukan dapat disimpulkan bahwa formula krim ekstrak kulit umbi bawang merah (Allium cepa L) dengan konsentrasi ekstrak 160 lebih baik dibandingkan formula dengan konsentrasi ekstrak $0,32 \%$ dilihat dari perbedaan hasil uji daya lekat dan daya sebar yang dihasilkan oleh formula 1 lebih baik. Krim dengan konsentrasi zat aktif $0,16 \%$ memiliki mutu fisik yang stabil dalam penyimpanan. Penelitian ini bertujuan untuk mengetahui efektivitas antiinflamasi krim ekstrak kulit bawang merah dan untuk mengetahui konsentrasi krim ekstrak kulit bawang merah yang memiliki aktivitas antiinflamasi pada mencit putih jantan menggunakan metode rangsang panas dengan alat hot-plate dan metode induksi karagenan $1 \%$ pada telapak kaki mencit. Pada penelitian ini digunakan hewan coba berupa mencit jantan yang dibagi menjadi empat kelompok masing-masing terdiri dari enam ekor mencit. Kelompok A sebagai kontrol negatif diberi basis krim, kelompok B sebagai kontrol positif diberi emulgel Voltaren (Natrium diklofenak), kelompok $\mathrm{C}$ sebagai kelompok uji diberi krim ekstrak kulit bawang merah konsentrasi 0,16\%, kelompok D sebagai kelompok uji diberi krim ekstrak kulit bawang merah konsentrasi 0,32\%. Pengukuran volume inflamasi dilakukan selama 5 jam dengan interval 60 menit. Pengukuran daya antiinflamasi dilakukan dengan menggunakan Plastimometer. Hasil yang diperoleh menunjukkan bahwa krim ekstrak kulit bawang merah konsentrasi $0,16 \%$ dan $0,32 \%$ memiliki efek antiinflamasi pada mencit yang diinduksi karagenan dengan krim ekstrak kulit umbi bawang merah konsentrasi $0,32 \%$ memiliki efek antiinflamasi yang lebih tinggi dibandingkan krim ekstrak kulit umbi bawang merah konsentrasi $0,16 \%$.
\end{abstract}

Kata kunci: antiinflamasi, ekstrak kulit bawang merah, hot plate, karagenan, krim.

\begin{abstract}
Inflammation is a local reaction to infection or injury and involves more mediators. Inflammation has a high incidence, where inflammation can be caused by physical trauma, and infection or antigen reactions from an illness. One of the plants that can be used as anti-inflammatory is onion (Allium cepa L.). Red onion contains flavonoid compounds, namely quarsetin which is believed to be used as anti-inflammatory. Extraction was carried out by maceration using $96 \%$ ethanol, and then the extract was formulated into M / A cream and evaluated for physical quality including organoleptic test, homogeneity test, $\mathrm{pH}$ test, dispersion test, adhesion test and stability test on day 1 to week 6 . The results of the research that have been done can be concluded that the cream formula of shallot tuber extract (Allium cepa L.) with extract concentration of 160 is better than the formula with extract concentration of $0.32 \%$ seen from the difference in test results of sticky and scattered power produced by formula 1 better. Cream with $0.16 \%$ active substance concentration has stable physical quality in storage. This study aims to determine the effectiveness of anti-inflammatory cream onionskin extract and to determine the concentration of cream onionskin extract, which has anti-inflammatory activity with hotplate heat stimulation method and 1\% carrageenan induction method on the soles of the mice's feet. In this study used experimental animals in the form of male mice which were divided into four groups each consisting of six mice. Group A as a negative control was given a cream base, group B as a positive control was given Voltaren emulgel (diclofenac sodium), group $\mathrm{C}$ as a test group given a cream of shallot skin extract concentration of $0.16 \%$, group D as a test group given an onion skin extract cream concentration of $0.32 \%$. The measurement of inflammatory volume was carried out for 5 hours at 60 minute intervals. Anti-inflamatory measurements are carried out using a pletismometer. The results showed that the red onion skin extract
\end{abstract}

• email korespondensi: debby.eternity46@gmail.com 
concentration of $0.16 \%$ and $0.32 \%$ had an anti-inflammatory effect on carrageenan-induced mice and cream of shallot tuber skin extract concentration of $0.32 \%$ had a higher anti-inflammatory effect than the cream of onion tuber skin extract red concentration of $0.16 \%$.

Keywords: anti-inflammatory, carrageenan, cream, hot plate, onionskin extract

\section{PENDAHULUAN}

Back to nature yang menjadi tren saat ini membawa masyarakat kembali memanfaatkan bahan alam, termasuk pengobatan dengan tanaman berkhasiat obat (Wijayakusuma, 2008). Bawang merah dikenal luas sebagai tanaman tradisional yang banyak dimanfaatkan di masyarakat Indonesia, khususnya di Bali. Umbi bawang merah sering digunakan sebagai bumbu masakan dan tanaman obat yang bermanfaat sebagai antiinflamasi, antioksidan, analgetik antipiretik dan masih banyak lagi (Jaelani, 2007). Soemarie (2016) menyatakan bahwa kulit umbi bawang merah memiliki aktivitas antiinflamasi karena memiliki kandungan senyawa flavonoid seperti kuersetin yang diyakini dapat digunakan sebagai antiinflamasi (Filomena et al., 2007). Inflamasi atau radang merupakan reaksi lokal jaringan terhadap infeksi atau cedera dan melibatkan lebih banyak mediator. Inflamasi memiliki angka kejadian yang cukup tinggi, dimana inflamasi dapat disebabkan oleh trauma fisik, infeksi maupun reaksi antigen dari suatu penyakit (Yuliati, 2010). Pengobatan inflamasi yang selama ini dilakukan pada umumnya menggunakan obat-obatan modern yang memiliki efek samping yang tinggi. Obat modern yang biasa digunakan ialah obat antiinflamasi non-steroid (AINS) yang memiliki efek samping merugikan tubuh seperti iritasi lambung (Tjay, 2007).

Menurut penelitian Teresita et al., (2001) sebelumnya mengatakan bahwa, senyawa kuersetin yang terkandung dalam suatu ekstrak dapat memberikan aktivitas antiinflamasi pada tikus dan bawang merah mampu memberikan aktivitas antiinflamasi karena adanya senyawa kuersetin yang terkandung di dalamnya. Dan dari penelitian yang dilakukan oleh Soemarie (2016) menyatakan bahwa kuersetin dari kulit bawang merah memiliki aktivitas antiinflamasi dengan mampu menghambat pembentukan radang pada telapak kaki mencit yang diinduksi karagenin. Kuersetin berperan sebagai antiinflamasi yang mekanisme kerjanya menghambat kerja enzim siklooksigenase. Dimana peran enzim siklooksigenase adalah menstimulasi pelepasan reseptor nyeri dan inflamasi yaitu prostaglandin.

Salah satu tanaman yang dapat digunakan sebagai antiinflamasi adalah bawang merah
(Allium cepa L.). Bawang merah memiliki kandungan senyawa flavonoid yaitu kuarsetin yang diyakini dapat digunakan sebagai antiinflamasi (Filomena et al., 2007). Menurut penelitian yang dilakukan Soemarie (2016), menunjukkan bahwa ekstrak kulit bawang merah memiliki efek antiinflamasi pada mencit (Mus musculus) dengan dosis $50 \mathrm{mg} / \mathrm{kg} \mathrm{BB}, 100 \mathrm{mg} / \mathrm{kg} \mathrm{BB}, 200 \mathrm{mg} / \mathrm{kg} \mathrm{BB}$ yang diberikan secara oral memiliki efek antiinflamasi karena mampu menghambat pembentukan radang pada telapak kaki mencit yang diinduksi karagenan.

Berdasarkan aktivitas antiinflamasi yang dimiliki kulit bawang merah, maka perlu dikembangkan suatu sediaan farmasi yang mempermudah dalam penggunaannya yaitu sediaan krim. Sediaan krim memiliki sistem emulsi yang mudah dioleskan dengan tekstur yang lembut dan dapat digunakan pada bagian kulit yang luas. Krim tipe M/A (minyak dalam air) bersifat tidak berminyak, mudah menyebar pada kulit dan memberikan rasa dingin pada lokasi. Pengobatan anti radang sendiri dapat melalui berbagai rute pemberian, diantaranya secara topikal, sediaan yang diberikan secara topikal memberikan keuntungan dapat menghindari efek samping obat yang berupa iritasi lambung, akibat dari penghambatan pembentukan prostaglandin oleh obat-obat anti radang itu sendiri.

Berdasarkan uraian di atas, ekstrak kulit bawang merah terbukti memiliki efek antiinflamasi pada mencit melalui pemakaian secara oral. Pemakaian antiinflamasi secara oral dapat menimbulkan efek samping berupa iritasi lambung. Oleh karena itu, perlu dibuat sediaan antiinflamasi topikal untuk mengindari efek samping tersebut. Pada penelitian ini digunakan krim karena sediaan krim mempunyai 2 keuntungan pada kenyamanan saat dipakai, karena mengandung air yang memberikan rasa dingin, yang dapat mengurangi panas yang terjadi pada daerah radang. Air juga berfungsi sebagai enhancer, yang dapat meningkatkan permeabilitas obat menembus kulit tanpa menyebabkan iritasi atau kerusakan permanen struktur permukaan kulit (Swarbrick dan Boylan, 1995).

Beberapa hal yang mempengaruhi efektifitas krim yaitu salah satunya, kestabilan suatu zat merupakan suatu yang harus diperhatikan dalam membuat suatu formulasi suatu sediaan farmasi. 
Hal ini penting mengingat suatu sediaan biasanya diproduksi dalam jumlah yang besar dan memerlukan waktu yang cukup panjang untuk sampai ke tangan konsumen (Zulfa et al., 2017).

Oleh karena itu sediaan tersebut juga perlu diuji kestabilannya sesuai prosedur yang telah ditentukan. Sediaan krim yang stabil yaitu sediaan yang masih berada dalam batas yang dapat diterima selama masa periode penyimpanan dan penggunaan, yaitu sifat dan karakterisasinya tetap sama dengan yang dimilikinya pada saat dibuat. Adanya zat aktif diperkirakan mempengaruhi kestabilan fisik dari setiap formulasi krim yang dibuat. Pada penelitian ini akan dilakukan uji stabilitas fisik krim yang mengandung ekstrak kulit umbi bawang merah (Herda et al., 2017).

Berdasarkan aktivitas antinflamasi dari kulit bawang merah, peneliti tertarik untuk melakukan uji efek antiinflamasi sediaan krim dari ekstrak kulit bawang merah pada mencit yang diinduksi karagenan.

\section{METODE PENELITIAN}

Rancangan Penelitian. Penelitian ini merupakan penelitian eksperimental untuk melihat efek antiinflamasi dari krim ekstrak kulit umbi bawang merah (Allium cepa L.) yang diformulasikan dalam jumlah zat aktif yang berbeda yaitu $0,16 \%$ dan $0,32 \%$ dengan 24 mencit putih sebagai hewan coba dengan pengelompokan jumlah 4 kelompok perlakuan dengan masing - masing kelompok 6 hewan coba, Kelompok $1($ Kontrol + ) diberikan voltaren emulgel, Kelompok 2 (Kontrol -) diberikan basis krim, Kelompok 3 (Dosis krim 1) diberikan krim ekstrak kulit bawang merah konsentrasi $0.16 \%$, Kelompok 4 (Dosis krim 2) diberikan krim ekstrak kulit bawang merah konsentrasi $0.32 \%$. Masing - masing kelompok perlakuan dioleskan sediaan pada telapak kaki mencit dan dibiarkan beberapa waktu sebelum di baca hasilnya menggunakan pletismometer.

Tabel 1. Formulasi Krim Ekstrak Kulit Umbi Bawang Merah

\begin{tabular}{lccl}
\hline \multirow{2}{*}{ Bahan } & \multicolumn{2}{c}{ Konsentrasi } & \multirow{2}{*}{ Fungsi } \\
\cline { 2 - 3 } & FI & FII & \\
\hline $\begin{array}{l}\text { Ekstrak kulit } \\
\text { bawang } \\
\text { merah }\end{array}$ & $0,16 \%$ & $0,32 \%$ & Bahan aktif \\
\hline Asam stearat & $12 \%$ & $12 \%$ & Fase Minyak \\
\hline Setil alkohol & $2 \%$ & $2 \%$ & Fase Minyak \\
\hline Trietanolamin & $2 \%$ & $2 \%$ & Fase Air \\
\hline Gliserin & $8 \%$ & $8 \%$ & Fase Air \\
\hline Metil paraben & $0,2 \%$ & $0,2 \%$ & Pengawet \\
\hline Aquadest & Ad 100 & Ad 100 & Pelarut \\
\hline
\end{tabular}

Bahan. Bahan yang digunakan dalam penelitian ini adalah kulit bawang merah (Allium cepa L.) dengan $60-70 \%$ daun sudah mulai rebah atau dilakukan pemeriksaan umbi secara acak yang diperoleh dari Desa Songan, Kecamatan Kintamani, Kabupaten Bangli dan telah dideterminasi di Lembaga Ilmu Pengetahuan Indonesia UPT Balai Konservasi Tumbuhan Kebun Raya "EKA RAYA" Bali, setil alkohol, asam stearat, trietanolamin, gliserin, metil paraben, aqua destillata, karagenan, $\mathrm{NaCl}$.

Alat. Alat yang digunakan dalam penelitian ini adalah alat-alat gelas yang umum terdapat di laboratorium kimia, sudip, kertas perkamen, mortir dan stamper, cawan porselen, termometer, $\mathrm{pH}$ universal, penangas air, gelas obyek, timbangan analitik (Lucky®, model DJ V220 A), blender, rotary evaporator, oven, pletismometer, hot-plate.

Hewan Percobaan. Pada pengujian ini digunakan hewan percobaan berupa mencit putih jantan (Mus musculus) sehat berumur 2-3 bulan yang memiliki kondisi fisik sehat dan aktif.

Pembuatan Ekstrak. Proses ekstraksi kulit bawang merah digunakan metode maserasi dengan pelarut etanol 96\%. Sebanyak 500 gram serbuk simplisia kulit bawang merah selama 3 hari dengan pelarut baru. Maserat disaring, hasil maserasi dan remaserasi dicampur lalu diuapkan menggunakan rotary evaporator hingga menjadi ekstrak pekat. Lalu diuapkan ekstrak pekat di oven dengan suhu 400C. Hingga di dapat ekstrak kental dimaserasi dengan pelarut etanol $96 \%$ dengan perbandingan (1:10) selama 3-4 hari dengan sesekali diaduk. Maserat di saring dengan corong Buchner. Lalu ampas diremaserasi.

\section{Pembuatan Krim Ekstrak Kulit Bawang} Merah. Untuk membuat 100 gram krim ekstrak kulit bawang merah, masing-masing bahan ditimbang sesuai formulasi. Bahan fase minyak (asam stearat dan setil alkohol) dan fase air (TEA, gliserin, metil paraben dan air) dipisahkan dengan ditampung pada beaker glass $250 \mathrm{ml}$. Dilarutkan metil paraben kedalam TEA setelah larut dimasukkan gliserin dan air ad 100 gram. Di panaskan fase minyak dan fase air hingga suhu yang sama sekitar $70^{\circ} \mathrm{C}-80^{\circ} \mathrm{C}$. Setelah semuanya melebur dan memiliki suhu yang sama, campurkan fase minyak dan fase air dalam mortir kemudian di aduk dengan konstan hingga homogen dan terbentuk masa krim. Terakhir dimasukkan ekstrak kulit bawang merah yang dilarutkan dengan sedikit 
etanol 96\% aduk hingga homogen. Krim dimasukkan ke dalam wadah yang sesuai.

Pembuatan Karagenan 1\%. Karagenan ditimbang sebanyak 100 gram, disiapkan $\mathrm{NaCl} 10$ $\mathrm{ml}$, karagenan dimasukkan ke dalam labu ukur 10 $\mathrm{ml}$, ditambahkan $\mathrm{NaCl}$ sedikit demi sedikit sampai garis tanda, dikocok hingga tercampur.

Pengujian Mutu fisik krim ekstrak kulit bawang merah. Pengujian dilakukan pada minggu ke 1,2,3,4,5,6 dilakukan pengujian homogenitas, uji $\mathrm{pH}$, uji organoleptis, uji daya sebar, uji daya lekat dan uji stabilitas (centrifuge). Pengujian mutu fisik sediaan krim ekstrak kuersetin kulit bawang merah dilakukan dalam beberapa tahap. Pengambilan data dilakukan pada minggu ke 1,2, $3,4,5,6$.

Analisis Data. Analisis data dilakukan dengan cara deskriptif, untuk menghitung efek antiinflamasi, dilakukan perhitungan dalam persen (\%) efek antiinflamasi dengan cara membandingkan volume udema dengan volume kaki normal pada hewan uji dengan rumus:

$$
\% \text { Volume Udema }=\frac{\mathrm{Vt}-\mathrm{Vo}_{\mathrm{o}}}{\mathrm{V}_{\mathrm{o}}} \times 100 \%
$$

Keterangan:

$\mathrm{Vt} \quad=$ Volume kak mencit pada waktu ke-t

Vo $=$ Volume kaki mencit sebelum diinjeksi karagenan $1 \%$

Data yang diperoleh dianalisis dengan menggunakan program statistika metode SPSS 22 for windows. Untuk mengetahui sebaran data normal atau tidak, dilakukan uji normalitas Kolmogrov-Smirnov selanjutnya dilakukan uji Kruskal-Wallis dan Post Hoc Mann-Whitney.

Pengujian Antiinflamasi. Pada penelitian ini dua puluh empat ekor mencit jantan dikelompokkan menjadi 4 kelompok secara acak, masing-masing kelompok terdiri dari 6 ekor mencit. Sebelum dilakukan pengujian, mencit terlebih dahulu diadaptasi selama 7 hari pada lingkungan laboratorium. Kelompok A sebagai kontrol negatif diberi basis krim, kelompok B kontrol positif sebagai pembanding diberi Voltaren emulgel, kelompok C sebagai kelompok uji diberi krim ekstrak kulit bawang merah konsentrasi $0,16 \%$ dan kelompok D sebagai kelompok uji diberi krim ekstrak kulit bawang merah konsentrasi $0,32 \%$. Masing-masing mencit diberi tanda pada ekornya kemudian ditimbang sebelum perlakuan dan sebelum perlakuan selama 7 hari adaptasi untuk melihat kenaikan berat badan hewan uji selama adaptasi. Masing-masing kelompok diberi rangsangan panas terlebih dahulu dengan menggunakan alat hot-plate pada suhu 55oC, diamati respon yang terjadi dimana mencit akan merasakan nyeri dan panas yang ditandai dengan menjilati kaki belakang dan melompat dari tabung pembatas kemudian Di injeksi karagenan 1\% sebanyak $0,1 \mathrm{ml}$ secara sublantar pada telapak kaki kiri mencit. Diukur volume normal telapak kaki kiri dengan mencelupkannya ke dalam cairan raksa sampai batas tanda pada alat pletismometer, 30 menit kemudian diberikan sediaan secara topikal berdasarkan kelompok uji masing - masing, perlakuan pada hewan uji dilakukan setiap 60 menit selama 300 menit kemudian diukur persen udem kaki hewan uji menggunakan pletismometer.

\section{HASIL DAN PEMBAHASAN}

Pada penelitian ini telah dilakukan pengujian untuk mengetahui efek antiinflamasi dari krim ekstrak kulit bawang merah (Allium cepa L.) pada mencit putih jantan (Mus musculus). Formulasi dibuat krim dari ekstrak kulit bawang merah sebanyak 2 formula dengan konsentrasi zat aktif berbeda. Dalam penelitian ini dilakukan pengujian mutu fisik sediaan krim dari ekstrak kulit bawang merah meliputi, uji organoleptis, uji homogenitas, uji $\mathrm{pH}$, uji daya sebar, uji daya lekat, dan uji stabilitas.

Pada uji organoleptis warna krim konstan sampai penyimpanan 6 minggu. Perubahan warna krim ini tidak berpengaruh terhadap stabilitas dan mutu fisik krim setelah penyimpanan 6 minggu sehingga penelitian tetap dilanjutkan. Bau dari sediaan krim tidak berbau.

Pengujian homogenitas kedua formulasi krim selama 6 minggu menunjukan hasil yang homogen. Hasil ini dilihat dari krim yang ditempatkan pada kaca preparat dan diberi beban pada kaca preparat juga tidak terdapat gumpalan ataupun gelembung. Uji $\mathrm{pH}$ dari sediaan krim adalah 7. Kadar $\mathrm{pH}$ dari kedua formula tersebut telah sesuai karena batas normal $\mathrm{pH}$ kulit adalah 4,5-7 (Juwita, 2013). 
Tabel 2. Hasil Pengukuran Daya Lekat

\begin{tabular}{ccccccc}
\hline \multirow{2}{*}{ Formula } & \multicolumn{5}{c}{ Daya Lekat minggu ke-(detik) } \\
\cline { 2 - 7 } & $\begin{array}{c}\text { Minggu } \\
\text { ke-1 }\end{array}$ & $\begin{array}{c}\text { Minggu ke- } \\
\mathbf{2}\end{array}$ & $\begin{array}{c}\text { Minggu } \\
\text { ke-3 }\end{array}$ & $\begin{array}{c}\text { Minggu } \\
\text { ke-4 }\end{array}$ & $\begin{array}{c}\text { Minggu } \\
\text { ke-5 }\end{array}$ & $\begin{array}{c}\text { Minggu } \\
\text { ke-6 }\end{array}$ \\
\hline $\begin{array}{c}\text { F1 } \\
(0,16 \%)\end{array}$ & 2,58 & 2,59 & 3,72 & 5,97 & 5,03 & 5,10 \\
\hline $\begin{array}{c}\text { F } 2 \\
(0,32 \%)\end{array}$ & 1,44 & 2,10 & 2,79 & 3,47 & 2,59 & 3,12 \\
\hline
\end{tabular}

Hasil uji daya lekat dari kedua formulasi bervariasi pada setiap minggunya yaitu pada formula 1 minggu ke-1 2,58 detik, ke-2 2,59 detik, ke-3 3,72 detik, ke-4 5,97 detik, ke-5 5,03 detik, ke-6 5,10 detik. Sedangkan formula 2 ke-1 1,44 detik, ke-2 2,10 detik, ke-3 2,79 detik, ke-4 3,47 detik, ke-5 2,59 detik, ke-6 3,12 detik. Dari kedua formula yang menjukkan hasil yang lebih baik yaitu pada formula 1 dengan konsentrasi ekstrak $0,16 \%$ karena daya lekat lebih lama, sehingga apabila diaplikasikan pada permukaan kulit lebih baik. Hasil itu sudah sesuai dengan persyaratan daya lekat krim yang baik yaitu lebih dari 4 detik (Wasiaatmadja, 1997).

Pengujian terakhir adalah pengujian pemisahan terhadap krim menggunakan alat centrifuge. Krim dimasukkan dalam tabung centrifuge, kemudian diputar pada 3000 rpm selama 30 menit, diamati apakah terjadi pemisahan (Ansel, 1989).

Tabel 3. Hasil Pengukuran Daya Sebar formula I dan II

\begin{tabular}{|c|c|c|c|c|c|c|c|c|c|c|c|c|}
\hline \multirow{3}{*}{$\begin{array}{c}\text { Beban } \\
\text { Berat tutup } \\
\text { kaca }\end{array}$} & \multicolumn{12}{|c|}{ Daya Sebar $(\mathrm{cm})$ minggu ke- } \\
\hline & \multicolumn{2}{|c|}{1} & \multicolumn{2}{|c|}{2} & \multicolumn{2}{|c|}{3} & \multicolumn{2}{|c|}{4} & \multicolumn{2}{|c|}{5} & \multicolumn{2}{|c|}{6} \\
\hline & $49 \mathrm{~g}$ & $47 \mathrm{~g}$ & $46 \mathrm{~g}$ & $47 \mathrm{~g}$ & $47 \mathrm{~g}$ & $49 \mathrm{~g}$ & $45 \mathrm{~g}$ & $47 \mathrm{~g}$ & $47 \mathrm{~g}$ & $44 \mathrm{~g}$ & $47 \mathrm{~g}$ & $49 \mathrm{~g}$ \\
\hline Tutup kaca & 5,25 & 5,5 & 4,5 & 5,25 & 4,75 & 5,5 & 4,25 & 5,5 & 4,5 & 5 & 4,25 & 5 \\
\hline $\begin{array}{c}\text { Kaca+beban } \\
50 \text { gram }\end{array}$ & 6,25 & 6 & 5 & 6,5 & 5,5 & 6,75 & 5 & 7 & 5,5 & 6 & 5 & 7,25 \\
\hline $\begin{array}{c}\text { Kaca + beban } \\
100 \text { gram }\end{array}$ & 6,5 & 6,5 & 6 & 7 & 6 & 7,25 & 5,5 & 7,75 & 6 & 6,5 & 5,5 & 7,75 \\
\hline
\end{tabular}

Dari hasil daya sebar krim selama penyimpanan di dapat hasil pada formula 1 yaitu minggu ke- $16,5 \mathrm{~cm}$, ke-2 $6 \mathrm{~cm}$, ke-3 $6 \mathrm{~cm}$, ke-4 $5,5 \mathrm{~cm}$, ke-5 $6 \mathrm{~cm}$, ke- $65,5 \mathrm{~cm}$. Pada formula 2 yaitu minggu ke- $16,5 \mathrm{~cm}$, ke- $27 \mathrm{~cm}$, ke- $37,25 \mathrm{~cm}$, ke-4 7,75 cm, ke-5 6,5 cm, ke-6 7,75 cm. Sesuai dengan persyaratan daya sebar untuk sediaan topikal yaitu sekitar 5-7 $\mathrm{cm}$ jadi yang memenuhi persyaratan yaitu pada formula 1 (Wasiaatmadja, 1997) dibandingkan dengan formula $0,32 \%$ yang daya sebarnya melebihi literatur daya sebar kulit yaitu $5-7 \mathrm{~cm}$ sedangkat hasil yang didapatkan pada formula $0,32 \%$ lebih dari persyaratan.

Metode pengujian efek antiinflamasi yang dilakukan dalam penelitian ini metode rangsang panas dengan alat hot-plate dan metode induksi karagenan $1 \%$ pada telapak kaki mencit. Hewan percobaan yang digunakan adalah mencit putih jantan, jenis kelamin jantan dipilih karena mencit jantan memiliki kestabilan hormonal dibanding mencit betina, karena mencit betina mengalami siklus masa menstruasi, kehamilan dan menyusui yang akan mempengaruhi kondisi psikologi hewan uji. Pada uji antiinflamasi ini menggunakan 4 kelompok perlakuan yaitu kelompok kontrol negatif menggunakan basis krim, kelompok kontrol positif voltaren emulgel, kelompok ekstrak kulit bawang merah $0,16 \%$ dan kelompok ekstrak kulit bawang merah $0,32 \%$. Pemilihan Natrium diklofenak sebagai kontrol positif karena natrium diklofenak memiliki daya antiradang yang paling kuat. Penggunaan karagenan $1 \%$ sudah mampu menimbulkan udem, hal ini dapat dilihat dari tabel sebelum perlakuan dan setelah perlakuan dimana terdapat perbedaan persen volume udem. Sebelum dan setelah diberikan induksi karagenan, mencit diberi rangsangan panas menggunakan hot-plate pada suhu 55oC yang bertujuan agar telapak kaki mencit menjadi lebih panas dan bengkak dari sekelilingnya karena lebih banyak darah dialirkan dari dalam tubuh ke permukaan daerah yang terkena rangsang panas dibandingkan daerah yang normal. 
Tabel 4. Rata-rata persen radang pada telapak kaki mencit

\begin{tabular}{ccccc}
\hline \multirow{2}{*}{$\begin{array}{c}\text { Waktu } \\
\text { (Menit) }\end{array}$} & Kontrol Negatif & Kontrol Positif & Ekstrak 0,16\% & Ekstrak 0,32\% \\
\hline 0 & $0 \pm 0$ & $0 \pm 0$ & $0 \pm 0$ & $0 \pm 0$ \\
\hline 30 & $47,37 \pm 15,61$ & $52,04 \pm 24,14$ & $48,25 \pm 16,17$ & $42,76 \pm 13,53$ \\
\hline 60 & $72,87 \pm 19,58$ & $54,54 \pm 9,83$ & $65,35 \pm 16,67$ & $65,05 \pm 15,56$ \\
\hline 120 & $86,72 \pm 14,01$ & $38,60 \pm 22,06$ & $56,99 \pm 18,09$ & $53,32 \pm 15,52$ \\
\hline 180 & $107,79 \pm 10,88$ & $33,98 \pm 14,19$ & $46,95 \pm 22,41$ & $37,73 \pm 12,20$ \\
\hline 240 & $118,61 \pm 11,62$ & $19,32 \pm 4,70$ & $34,88 \pm 18,99$ & $20,47 \pm 09,32$ \\
\hline 300 & $131,10 \pm 11,13$ & $-1,75 \pm 5,63$ & $20,96 \pm 13,92$ & $6,89 \pm 5,39$ \\
\hline
\end{tabular}

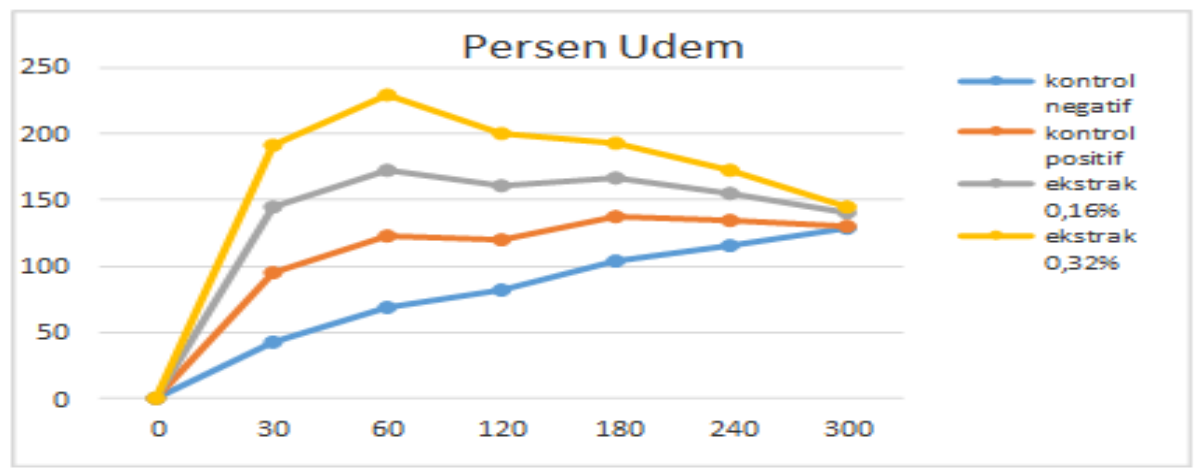

Gambar 1. Diagram garis hubungan rata-rata persen udem terhadap waktu

Berdasarkan hasil pengujian antiinflamasi terlihat pada semua krim kelompok uji menunjukkan adanya efek antiinflamasi dimana persen udem rata-rata setiap kelompok zat uji tidak sebesar persen udem pada kelompok kontrol negatif. Pada kelompok kelompok kontrol negatif yang hanya diberi basis krim, persen udem terus meningkat dari menit ke 30 hingga menit ke 300. Pada kelompok uji dan kelompok kontrol negatif terjadi peningkatan persentase udem pada menit ke 30 sampai menit ke 60 dan mengalami penurunan pada menit ke 120 sampai menit ke 300. Pada ratarata persen udem pada kelompok krim ekstrak kulit bawang merah konsentrasi 0,16\% lebih besar dibandingkan dengan kelompok ekstrak kulit bawang merah konsentrasi $0,32 \%$ dan kelompok kontrol positif. Sehingga pemberian krim ekstrak kulit bawang merah konsentrasi $0,32 \%$ merupakan konsentrasi yang berpotensi tinggi dalam menghambat udem. Suatu bahan dikatakan memiliki efek antiinflamasi jika pada hewan coba yang diinduksi karagenan $1 \%$ mengalami pengurangan pembengkakan hingga $50 \%$ atau lebih (Utami et al., 2011 dalam Ira 2013).

Analisa awal dilakukan uji normalitas dengan menggunakan metode Kolmogorov Smirnov yang bertujuan untuk melihat distribusi persen volume udem pada telapak kaki mencit normal atau tidak. Hasil dari pengujian normalitas didapatkan bahwa data persentase udem tidak terdistribusi normal $(\mathrm{p}<0,05)$. Pengelolaan data tidak dapat dilanjutkan menggunakan ANOVA karena tidak memenuhi syarat ANOVA maka dialanjutkan dengan uji Kruskal Wallis untuk mengetahui apakah ada perbedaan secara bermakna atau tidak pada setiap kelompok perlakuan. Hasil uji Kruskal Wallis diketahui bahwa terdapat perbedaan bermakna pada setiap kelompok perlakuan $(\mathrm{p}<0,05)$ sehingga dilanjutkan dengan uji Mann Whitney.

Hasil statistik data persentase udem dinyatakan bahwa kelompok kontrol negatif tidak berbeda bermakna ( $>>0,05)$ dengan kelompok kontrol positif, kelompok ekstrak kulit bawang merah $0,16 \%$ dan kelompok ekstrak kulit bawang merah $0,16 \%$ pada menit ke 30 dan 60 tetapi berbeda bermakna $(p<0,05)$ pada menit ke 120 sampai 300. Berdasrkan hasil tersebut dapat simpulkan bahwa krim ekstrak kulit bawang merah memiliki efek antiinflamasi yang baru terlihat pada menit ke 120 sampai 300.

Perbandingan kelompok kontrol positif dengan kelompok F1 dan F2 menunjukkan bahwa kelompok F3 tidak berbeda secara bermakna $(p>0,05)$. Artinya kelompok F3 kemampuan penurunan udem setara dengan kontrol positif. 
Pada kelompok F2 memiliki perbedaan bermakna ( $\mathrm{p}<0,05)$ pada menit ke 240 dan 300, sedangkan pada menit ke 30 sampai 180 tidak berbeda bermakna $(\mathrm{p}>0,05)$. Artinya kemampuan penurunan udem F2 berbeda dengan kontrol positif.

Perbandingan antara krim F2 dan F3 berbeda secara bermakna $(\mathrm{p}<0,05)$ pada menit ke 240 dan 300, sedangkan pada menit ke 30 sampai 180 tidak berbeda bermakna ( $>>0,05)$. Artinya kelompok F2 memiliki aktivitas antiinflamasi yang lebih baik pada menit ke 240 dan 300 sedangkan pada menit ke 30 sampai 180 aktivitas antiinflamasinya setara. Hasil penurunan yang berpotensi tinggi menurunkan inflamasi dapat dilihat dari persentase, dimana krim ekstrak kulit bawang merah $0,32 \%$ memiliki persentase penghambatan terbesar. Krim ekstrak kulit bawang merah 0,32\% menurunkan inflamasi lebih besar dibandingkan krim ekstrak kulit bawang merah 0,16\%.

Penelitian ini menunjukkan bahwa ekstrak kulit bawang merah dapat menurunkan inflamasi dimana aktivitas antiinflamasi berkaitan dengan penghambatan pembentukan siklooksigenase dengan kuarsetin sebagai senyawa yang berperan sebagai antiinflamasi yang mekanisme kerjanya menghambat kerja enzim siklooksigenase pada jalur asam arakidonat.

\section{KESIMPULAN}

Berdasarkan hasil penelitian yang telah dilakukan dapat disimpulkan bahwa:

Krim ekstrak kulit bawang merah (Allium cepa L.) memiliki mutu fisik yang stabil selama penyimpanan.

Krim ekstrak kulit umbi bawang merah (Allium cepa L.) memiliki aktifitas antiinflamasi dimana krim ekstrak kulit umbi bawang merah konsentrasi $0,32 \%$ memiliki efek antiinflamasi yang lebih tinggi dibandingkan krim ekstrak kulit umbi bawang merah konsentrasi $0,16 \%$ dengan daya hambat sebesar $94,74 \%$.

\section{DAFTAR PUSTAKA}

Andini, Rika, 2018, Efek Analgesik Gel Infusa Daun Mengkudu (Morinda citriolia L.) pada mencit putih jantan (Mus musculus) Galur Balb/c, Karya Tulis Ilmiah Akademi Farmasi Saraswati Denpasar.

Agoes, Goeswin. 2009. Tekonologi Bahan Alam. Bandung: ITB
Ansel, H, 1989. Pengantar Bentuk Sediaan Farmasi. Jakarta Penerbit Universitas Indonesia (UI-press)

Astuti, D,Puji., Husni, Patihul., Hartono, Kusdi, Formulasi dan Uji Stabilitas Fisik Sediaan Gel Antiseptik Tangan Minyak Atsiri Bunga Lavender (Lavandula angustifolia Miller). Sumedang. Jawa Barat. Fakultas Farmasi. Universitas Padjadjaran.

Depkes RI., 1979, Farmakope Indonesia, Edisi III, Departemen Kesehatan Republik Indonesia, Jakarta.

Depkes RI., 2002. Parameter Standar Umum Ekstrak Tumbuhan Obat,.Departemen Kesehatan Republik Indonesia, Jakarta.

Dorland, W.A. Newman.2012. Kamus Kedokteran Dorlan, edisi 28. Jakarta: Buku Kedokteran EGC.

Muthia, Indah. 2017, Efek Antiinflamasi Ekstrak Etanol Daun Salam India (Murraya koenigii L.). Denpasar, Akademi Farmasi Saraswati Denpasar.

Nawangsari, Dwi. 2008. Pemanfaatan Bawang Merah (Allium Cepa L.) Sebagai Kemoterapi. Yogyakarta : Fakultas Farmasi Universitas Gadjah Mada.

Ningsi, Surya, 2016. Formulasi dan Uji Stabilitas Fisik Gel Ekstrak Daun Binahong (Andredera cordifolia). Makassar. Jurusan Farmasi Fakultas Ilmu Kesehatan Universitas Islam Negeri Alauddin.

Nugroho A.E. 2012. Farmakologi Obat-obat Penting dalam PembelajaranIlmu Farmasi dan Dunia Kesehatan, Yogyakarta: Pustaka Pelajar.

Rita, Trisnayanti, 2016, Uji Mutu Fisik Gel Ekstrak Etanol Daun Binahong Dengan Variasi Gelling Agent Karbomer dan CMC-Na. Akademi Farmasi Saraswati Denpasar.

Rowe, G.R., P.J.Sheskey, S.C.Owen, 2006, Handbook of PHarmaceutical Excipients 5th Edition, Pharmaceutical Press: London

Sampurno.2007. Obat Herbal Dalam Perspektif Medik dan Bisnis. Journal traditional medicine, Vol. 12(42) : 18-27 
Setyarini, Holida. 2009. Uji Daya Inflamasi Gel Ekstrak Etanol Jahe 10\% (Zingiber officinale Roscoe) yang Diberikan Topikal Terhadap Udem Kaki Tikus Ynag Diinduksi Karagenin. Surakarta, Universitas Muhammadiyah.

Soemarie,Y.B .,2016. Uji Aktivitas Antiinflamasi Kuersetin Kulit Merah (Allium cepa L.) pada Mencit putih jantan (Mus musculus). Karya tulis ilmiah, samarinda, Akademi Farmasi Samarinda.

Swarbrick, J. dan Boylan, J., 1995, Percutaneous Absorption, in Encyclopedia of Pharmaceutical Technology, Volume 11, Marcel Dekker Inc., New York,

Syamsuni,H.a,2006, Ilmu Resep. Jakarta. Penerbit Buku Kedokteran EGC
Tjay, T.H., dan Raharja, K. 2007. Obat-Obat Penting. Jakarta: PT. Gramedia

Wasito,H.2011, Obat Tradiosional Kekayaan Indonesia.Graha Ilmu. Yogyakarta

Widianti, Z. 2017. Efek Antiinflamasi Ekstrak Etanol Daun Zaitun (Olea europaea L.) Pada Edema Telapak Kaki Tikus Galur SpragueDawley yang Diinduksi Karagenan. Skripsi. Jakarta. Universitas Islam Negeri.

Yuliati, K.S. 2010. Efek Antiinflamasi Ekstrak Etanol Kulit Kacang Tanah (Arachis hypogaea L.) Pada Tikus Putih Jantan Galur Wistar Yang Diinduksi Karagenni. Skripsi. Surakarta: Fakultas Farmasi Muhammadiyah Surakarta 